\title{
RESULTS OF SURGERY IN PATIENTS WITH BILATERAL INDEPENDENT TEMPORAL LOBE SPIKING (BITLS) WITH NORMAL MRI OR BILATERAL MESIAL TEMPORAL SCLEROSIS (MTS) INVESTIGATED WITH BILATERAL SUBDURAL GRIDS
}

\author{
ARTHUR CUKIERT* , ALCIONE SOUSA**, ELCIOMACHADO**, \\ J OSE AUGUSTO BURATINI**, CASSIO FORSTER**, MEIRE ARGENTONI**
}

\begin{abstract}
Purpose: The introduction of new technologies in the clinical practice have greatly decreased the number of patients submitted to invasive recordings. On the other hand, some patients with refractory temporal lobe epilepsy have normal MR scans or bilateral potentially epileptogenic lesions. This paper reports the results of invasive neurophysiology and surgical outcome in such patients. Method: Sixteen patients were studied. Eleven had normal MRI (Group I) and five had bilateral mesial temporal sclerosis (Group II). All patients had BITLS and non-localizatory seizures on video-EEG monitoring. All patients were implanted bilaterally with $32-$ contacts subdural grids. They were submitted to a cortico-amygdalo-total hippocampectomy at the side defined by chronic electrocorticography (ECoG). Results: In Group I, seizures came from a single side in nine patients. In nine patients, seizures started at one side, spread to the ipsolateral contacts and contralaterally afterwards. On the other hand, in two Group I patients seizures started in one mesial region and spread to the contralateral parahippocampus and neocortex before spreading to ipsolateral contacts. All patients in Group II had seizures starting unilaterally with focal EcoG onset in the mesial regions. Eight Group I patients are seizure-free and three are in Engel's class II. Eighty percent of Group II patients are seizure-free after surgery and one patient is in Engel's class II. Conclusion: Good surgical results can be obtained in patients with BITLS. Patients with normal MRI seem to have a worse prognosis when compared to patients with unilateral or even bilateral MTS. Extensive subdural coverage is essential in patients with normal MRI.
\end{abstract}

KEY WORDS: bitemporal epilepsy, surgery, subdural grids, outcome, MRI.

Resultados cirúrgicos em pacientes com descargas bilaterais independentes do lobo temporal (DBILT) e ressonância magnética normal ou com esclerose mesial bilateral investigados com implante bilateral de gradessubdurais.

RESUMO - Introdução: A introdução de novas tecnologias na prática clínica tem diminuído em muito a necessidade do estudo com eletrodos invasivos em pacientes epilépticos refratários. Por outro lado, alguns pacientes com epilepsia do lobo temporal ainda possuem exames de imagem normais ou com lesões potencialmente epileptogênicas bilaterais. Este estudo relata os resultados da neurofisiologia invasiva e da cirurgia neste grupo de pacientes. Métodos: Dezesseis pacientes foram estudados. Onze possuíam RM normal (grupo I) e 5 esclerose mesial bilateral (grupo II). Todos possuíam DBILT e crises não-localizatórias após vídeo-monitorização. Todos foram implantados bilateralmente com placas subdurais de 32 contatos cada. Eles foram submetidos a córticoamigdalo-hipocampectomia do lado definido pela neurofisiologia invasiva. Resultado: No grupo I, as crises originaram-se em somente um lado em 9 pacientes. Em 9 pacientes, as crises iniciavam-se em um lado, espraiandose para os contatos ipsilaterais e a seguir contralateralmente. Por outro lado, em 2 pacientes do grupo I, as crises iniciavam-se na superfície mesial de um lado e espraiava-se inicialmente para a superfície mesial e neocórtex contralaterais, antes de invadir outros contatos ipsilaterais. Todos os pacientes do grupo II possuíam crises iniciandose na região mesial. Oito pacientes do grupo I estão sem crises e 3 encontram-se na classificação de Engel II. Oitenta por cento dos pacientes do grupo II estão sem crises após a cirurgia e um paciente encontra-se em Engel II. Conclusão: Bons resultados cirúrgicos podem ser obtidos em pacientes com DBILT. Pacientes com RM

Epilepsy Surgery Program, Hospital Brigadeiro and Clinica de Epilepsia de São Paulo, São Paulo SP, Brazil: *MD, PhD; **MD. Aceite: 9-agosto-2000.

Dr. Arthur Cukiert - R. Dr. Alceu Campos Rodrigues 247, 12 A , cj 121 -04544-000 São Paulo SP-Brasil. 
normal parecem ter prognóstico pior quando comparados com aqueles com esclerose mesial unilateral ou mesmo bilateral. Extensa cobertura subdural é necessária para o estudo invasivo de pacientes com RM normal.

PALAVRAS-CHAVE: epilepsia bitemporal, cirurgia, grades subdurais, resultados, RM.

Invasive recordings have been used to evaluate preoperatively patients with temporal lobe epilepsy (TLE). All patients with TLE published in the early series had been submitted to depth electrodes' implantation. New technologies such as video-EEG monitoring, neuropsychology, Wada's testing, PET and SPECT made it possible to progressively decrease the number of patients implanted with invasive electrodes. It was the introduction of MRI in the clinical practice that had a major impact on epilepsy surgery, demonstrating preoperatively lesions such as mesial temporal sclerosis (MTS) or cortical dysplasia (CD) that were well known pathological entities but were poorly evaluated noninvasively by the previous diagnostic methods. MRI further decreased the number of patients submitted to invasive recordings.

Invasive recordings in patients with bilateral independent temporal lobe spiking (BITLS) were obtained through the insertion of bilateral depth electrodes in the early series ${ }^{1}$. This was performed using stereotactic techniques and orthogonal or posterior entry points and the bilateral insertion of depth electrodes that perforated the brain, with their tips lying on the hippocampi ${ }^{2,3}$. Later, other types of electrodes such as foramen ovale, epidural and subdural electrodes were used either alone or in combination ${ }^{4-6}$. Subdural strips have also been used to cover the temporal lobes in these patients. They can be easily inserted through a burr-hole but their coverage is limited and their positioning is often not perfect. Extensive subdural coverage of the temporal lobe with grids has not been adequately described in the literature.

Many of the published series dealing with invasive monitoring of patients with BITLS were published before the introduction of MRI and dealt with heterogeneous groups of patients ${ }^{7,8}$. MRI not only made it possible to overcome the need for depth electrodes but also allowed us to evaluate very homogeneous groups of patients.

Patients with presumed TLE and BITLS and normal MRI or bilateral MTS still represent a challenge for preoperative focus localization. This paper describes the results of surgery in a series of these patients who were evaluated with extensive sub-dural grid coverage.

\section{METHOD}

Sixteen adult patients were studied. All patients had complex partial seizures (CPS) with automatisms and seven had simple partial seizures (SPS; four autonomic and three non-specific). All patients were submitted to high-resolution 1.5T MRI including thin T1, T2 and flair slices perpendicular to the hippocampal axis. All films were analysed visually. Eleven patients had normal MRI (Group I) and five had bilateral MTS (Group II). All patients had BITLS with at least $30 \%$ of the activity coming from one side in routine EEGs and non-localizatory seizures on video-EEG monitoring.

All patients were submitted to bilateral subdural grids implantation. Each 32-contacts $(8 \mathrm{x} 4)$ grid was implanted through an independent pterional craniotomy that included a $1.5 \mathrm{~cm}$ subtemporal craniectomy with full exposure of the temporal lobe and inferior frontal gyrus. After dissection of the basal temporal lobe region the most mesial row of four contacts was set in place lying over the parahippocampal gyrus under direct visualization. The two most cranial rows of four electrodes were positioned above the sylvian fissure, over the inferior frontal gyrus (Fig 1).

All patients were submitted to a cortico-amygdalo-hippocampectomy under general anesthesia with total hippocampal removal at the side defined by chronic eletrocorticographic (EcoG) monitoring. Follow-up time ranged from 10 to 30 months $(\mathrm{m}=14)$.

\section{RESULTS}

Thirty-two temporal lobes (16 patients) were implanted. In one temporal lobe, it was impossible to dissect the full parahippocampal extension due to severe adherences and the more mesial electrodes 


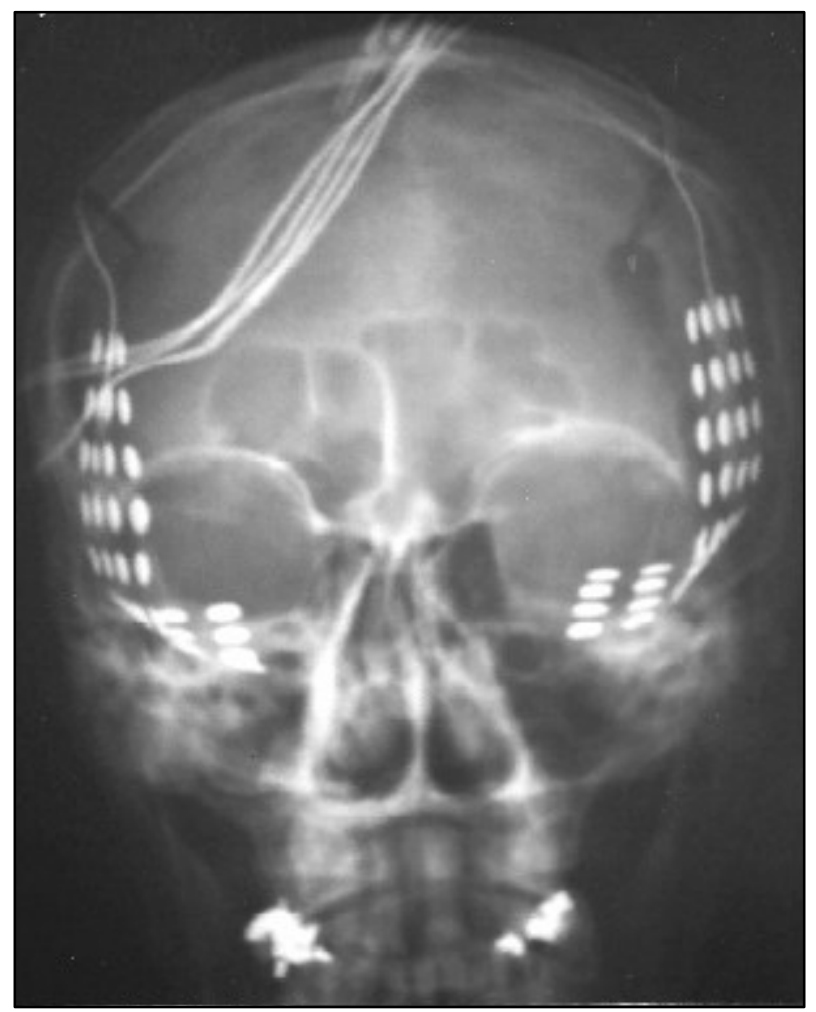

Fig 1. Skull X-ray showing the typical position of the bilaterally implanted subduralgrids.

were left in contact with the fusiform gyrus. In two temporal lobes (two patients) a more anterior insertion of the vein of Labbe made it necessary to reduce the grid from 32 (8x4) to 24 (8x3) contacts. Patients tolerated well the procedure. There was no sign or symptom of intracranial hypertension except for headache that lasted from two to five days. No patient received steroids. All of them received prophylatic antibiotics during the implantation period.

Seizures were recorded in all patients (3-10 seizures) after anti-epileptic drugs withdrawal. In Group I, seizures came from a single side in nine patients. In the other two patients, at least $80 \%$ of the seizures came from one side only. Two patients in Group I disclosed a more widespread regional onset of their seizures while nine had a focal onset (five neocortical, four mesial). In nine patients, seizures started at one side, spread to the ipsolateral contacts and contralaterally afterwards. On the other hand, in two Group I patients seizures started in one mesial region and spread to the contralateral parahippocampus and neocortex before spreading to ipsolateral contacts. All patients in Group II had seizures starting unilaterally with focal EcoG onset in the mesial regions.

Three patients (one in Group I and two in Group II) had interictal spiking prevailing over the non-resected temporal lobe. All three had been rendered seizure-free by surgery.

Eight Group I patients were seizure-free and three were in Engel's class II $^{9}$ postoperatively (one with regional and two with neocortical seizure's onset). Eighty percent of Group II patients are seizure-free after surgery and one patient was in Engel's class II (at least 90\% improvement). There was no neurologic morbidity (Table 1). 
Table 1. Clinical summary of the series.

\begin{tabular}{|c|c|c|c|c|c|c|c|}
\hline Patient & $\begin{array}{l}\text { Interictal EEG } \\
\text { predominance }\end{array}$ & MRI & ECoG ictal onset & $\begin{array}{l}\text { Contralateral } \\
\text { spread }\end{array}$ & Ictal onset & Outcome & Pathology \\
\hline 1 & $\begin{array}{l}\text { ipsolateral } \\
\text { to surgery }\end{array}$ & normal & focal mesial & $\begin{array}{l}\text { before } \\
\text { ipsolateral }\end{array}$ & unilateral & I & HS \\
\hline 2 & $\begin{array}{l}\text { ipsolateral } \\
\text { to surgery }\end{array}$ & normal & focal mesial & $\begin{array}{c}\text { before } \\
\text { ipsolateral }\end{array}$ & unilateral & I & normal \\
\hline 3 & $\begin{array}{l}\text { ipsolateral } \\
\text { to surgery }\end{array}$ & normal & focal neocortical & $\begin{array}{c}\text { after } \\
\text { ipsolateral }\end{array}$ & bilateral & II & normal \\
\hline 4 & $\begin{array}{l}\text { ipsolateral } \\
\text { to surgery }\end{array}$ & normal & focal neocortical & $\begin{array}{c}\text { after } \\
\text { ipsolateral }\end{array}$ & unilateral & II & normal \\
\hline 5 & $\begin{array}{l}\text { ipsolateral } \\
\text { to surgery }\end{array}$ & normal & focal neocortical & $\begin{array}{c}\text { after } \\
\text { ipsolateral }\end{array}$ & unilateral & I & $\mathrm{CD}$ \\
\hline 6 & $\begin{array}{c}\text { contralateral } \\
\text { to surgery }\end{array}$ & normal & focal neocortical & $\begin{array}{c}\text { after } \\
\text { ipsolateral }\end{array}$ & unilateral & I & normal \\
\hline 7 & $\begin{array}{l}\text { ipsolateral } \\
\text { to surgery }\end{array}$ & normal & focal neocortical & $\begin{array}{c}\text { after } \\
\text { ipsolateral }\end{array}$ & bilateral & I & normal \\
\hline 8 & $\begin{array}{l}\text { ipsolateral } \\
\text { to surgery }\end{array}$ & normal & focal mesial & $\begin{array}{c}\text { after } \\
\text { ipsolateral }\end{array}$ & unilateral & I & HS \\
\hline 9 & $\begin{array}{l}\text { ipsolateral } \\
\text { to surgery }\end{array}$ & normal & focal mesial & $\begin{array}{c}\text { after } \\
\text { ipsolateral }\end{array}$ & unilateral & I & HS \\
\hline 10 & $\begin{array}{l}\text { ipsolateral } \\
\text { to surgery }\end{array}$ & normal & regional & $\begin{array}{c}\text { after } \\
\text { ipsolateral }\end{array}$ & unilateral & II & normal \\
\hline 11 & $\begin{array}{l}\text { ipsolateral } \\
\text { to surgery }\end{array}$ & normal & regional & $\begin{array}{c}\text { after } \\
\text { ipsolateral }\end{array}$ & unilateral & I & normal \\
\hline 12 & $\begin{array}{l}\text { ipsolateral } \\
\text { to surgery }\end{array}$ & bilateralMTS & focal mesial & $\begin{array}{c}\text { after } \\
\text { ipsolateral }\end{array}$ & unilateral & II & HS \\
\hline 13 & $\begin{array}{l}\text { contralateral } \\
\text { to surgery }\end{array}$ & bilateralMTS & focal mesial & $\begin{array}{c}\text { after } \\
\text { ipsolateral }\end{array}$ & unilateral & I & HS \\
\hline 14 & $\begin{array}{l}\text { ipsolateral } \\
\text { to surgery }\end{array}$ & bilateralMTS & focal mesial & $\begin{array}{c}\text { after } \\
\text { ipsolateral }\end{array}$ & unilateral & I & $\mathrm{HS} / \mathrm{CD}$ \\
\hline 15 & $\begin{array}{l}\text { ipsolateral } \\
\text { to surgery }\end{array}$ & bilateralMTS & focal mesial & $\begin{array}{c}\text { after } \\
\text { ipsolateral }\end{array}$ & unilateral & I & HS \\
\hline 16 & $\begin{array}{l}\text { contralateral } \\
\text { to surgery }\end{array}$ & bilateralMTS & focal mesial & $\begin{array}{c}\text { after } \\
\text { ipsolateral }\end{array}$ & unilateral & I & HS \\
\hline
\end{tabular}

HS, hippocampal sclerosis; CD, cortical dysplasia; MTS, mesial temporal sclerosis. Outcome was rated according to Engel's outcome scale.

\section{DISCUSSION}

This paper deals with two different homogeneous populations with refractory TLE as defined by MRI. We do not submit patients with unilateral MTS or focal lesions to invasive recordings. The MRI findings reported here did not include volumetric analysis (VA). VA would probably not introduce any new data in Group II patients (with bilateral MTS at visual inspection) but might have eventually detected minor differences in the hippocampi in Group I patients. On the other hand, our invasive recordings showed that 7 out of 11 patients in Group I had neocortical ictal onset which is compatible with healthy-looking hippocampi on MRI. Thus, VA might have been useful in 4 out of 11 patients in Group I but this should be regarded as additional data only and invasive recording would still be necessary. 
Contrary to what we have seen in Group I (63\% of neocortical seizure onset), no patient in Group II had a neocortical ictal onset or a contralateral early involvement. If this proves to be true as the series increases in numbers, such an extensive subdural coverage might not be necessary in patients with bilateral MTS. In these patients, bilateral placement of foramen ovale electrodes might be enough. On the other hand, limited coverage with subdural strips, epidural or foramen ovale electrodes in Group I patients would very likely lead to misdiagnosis.

Our worst results after temporal lobe resections were obtained in Group I patients (72\% seizure-free). This compares badly with the results obtained in our patients and those from other series with unilateral MTS (89\% seizure-free) $)^{10-14}$ or even bilateral MTS (Group II; 80\% seizurefree). Some of Group I patients might prove not to have TLE despite clinical and neurophysiological clues suggestive of a temporal lobe onset. Earlier series dealing with heterogeneous populations have not emphasized imaging findings ${ }^{15-18}$. The majority of Group I patients had no demonstrable pathology within the surgical specimen. Two patients in this series (1 in Group I and 1 in Group II) disclosed areas of $\mathrm{CD}$ in the surgical specimen not detected preoperatively and in three Group I patients the resected hippocampi were found to be sclerotic despite normal MRI appearance. This probably represents the limitations of MRI in the detection of these abnormalities.

Three of our patients had interictal spiking prevailing over the non-resected temporal lobe and were seizure-free after surgery. High prevalence of interictal spiking contralateral to the temporal lobe to be resected is not a contraindication for surgery and is not necessarily related to a bad surgical outcome.

Patients with BITLS and normal MRI or bilateral MTS still represent a challenge for the surgical treatment. Invasive recordings are still needed during their preoperative work-up.

\section{REFERENCES}

1. Olivier A, Gloor P, Quesnay LF, Andermann F. The indications for and the role of depth electrode recording in epilepsy. Appl Neurophysiol 1983;46:33-36.

2. Hirsch LJ, Spencer SS, Spencer DD, Williamson PD, Mattson RH. Temporal lobectomy in patients with bitemporal epilepsy defined by depth electroencephalography. Ann Neurol 1991;30:347-356.

3. So N, Gloor P, Quesnay LF, Jones-Gotman M, Olivier A, Andermann F. Depth electrode investigations in patients with bitemporal epileptiform abnormalities. Ann Neurol 1989;25:423-431.

4. Wyler A, Ojemann G, Lettich E, Ward A. Subdural strip electrodes for localizing epileptogenic foci. J Neurosurg 1984;60:1196-1200.

5. Rosembaum T, Laxer K, Vessely M, Smith W. Subdural electrodes for seizure focus localization. Neurosurgery 1986;19:73-81.

6. Blatt DR, Roper SN, Friedman WA. Invasive monitoring of limbic epilepsy using stereotactic depth and subdural electrodes: surgical technique. Surg Neurol 1997;48:74-79.

7. Bloom D, Jasper H, Rasmussen T. Surgical therapy in patients with temporal lobe seizures and bilateral EEG abnormality. Epilepsia 1960;1:351-365.

8. So N, Olivier A, Andermann F, Gloor P, Quesnay F. Results of surgical treatment in patients with bitemporal epileptiform abnormalities. Ann Neurol 1989;25:432-439.

9. Engel J Jr, vanNess P, Rasmussen T, Ojemann L, Outcome with respect to epileptic seizures. In Engel J Jr. (ed). Surgical treatment of the epilepsies. 2.Ed. edition. New York: Raven Press, 1993:609-621.

10. Forster C, Cukiert A, Andrioli M, Ferreira VB, Frayman L. Preoperative lateralization of temporal lobe foci based on MRI and interictal scalp EEG recordings. Epilepsia 1998;39(Suppl.6):84.

11. Cukiert A, Andrioli M, Forster C, Ferreira VB, Frayman L. Results of resective surgery in patients with bitemporal spiking and unilateral mesial temporal sclerosis. Epilepsia 1998; 39(Suppl.6):84.

12. Cendes F, Dubeau F, Andermann F, et al. Significance of mesial temporal atrophy in relation to intracranial ictal and interictal stereo-EEG abnormalities. Brain 1996;119:1317-1326.

13. Cascino GD, Trenerry MR, Sharbrough FW, So EL, Marsh WR, Strelow DC. Depth electrode studies in temporal lobe epilepsy: relation to quantitative resonance imaging and operative outcome. Epilepsia 1995;36:230-235.

14. Holmes MD, Dodrill CB, Ojemann GA, Wilenski AJ, Ojemann LM. Outcome following surgery in patients with bitemporal interictal epileptiform patterns. Neurology 1997;48:1037-1040.

15. Hirsch LJ, Spencer SS, Williamson PD, Spencer DD, Mattson RH. Comparison of bitemporal and unitemporal epilepsy defined by depth electroencephalography. Ann Neurol 1991;30:340-346.

16. Chung MY, Walczak TS, Lewis DV, Dawson DV, Radtke R. Temporal lobectomy and independent bitemporal interictal activity: what degree of lateralization is sufficient? Epilepsia 1991;32:195-201.

17. Benbadis SR, So NK, Antar MA, Barnett GH, Morris HH. The value of PET scan (and MRI and Wada test) in patients with bitemporal epileptiform discharges. Arch Neurol 1995;52:1062-1068.

18. Steinhoff BJ, So NK, Lim S, Luders HO. Ictal scalp EEG in temporal lobe epilepsy with unitemporal versus bitemporal epileptiform discharges. Neurology 1995;45:889-896. 